\title{
ANALISIS PENGARUH RASIO KEUANGAN, KEPEMILIKAN MANAJERIAL, DAN KEPEMILIKAN INSTITUSIONAL TERHADAP FINANCIAL DISTRESS PADA PERUSAHAAN SEKTOR PERDAGANGAN, JASA, DAN INVESTASI YANG TERDAFTAR DI BEI TAHUN 2015-2018
}

\author{
Ainnun Masita \\ Universitas Negeri Surabaya \\ ainunmasita13@gmail.com \\ Purwohandoko \\ Universitas Negeri Surabaya \\ purwohandoko@unesa.ac.id
}

\begin{abstract}
Financial distress causes the company to restructure or even going bankrupt. It means the prediction of financial distress is important to anticipate the occurrence of bankruptcy. This study aimed to determine the effect of financial ratios, managerial ownership, and institutional ownership on financial distress. The independent variables used in this study are the current ratio, debt to assets ratio, return on assets, total assets turnover, managerial ownership, and institutional ownership. This research's population is sector trade, services, and investment firms listed on the Indonesia Stock Exchange in 2015-2018. It implements purposive sampling techniques and finally obtained 15 firms as samples. The research then is analyzed using logistic regression and calculated using SPSS software version 25. The result showed that debt to assets ratio had a positive significance on financial distress and return on assets had a negative significant effect on financial distress. While the other variables of total assets turnover, current ratio, managerial ownership, institutional ownership don't have a significant effect on financial distress. Therefore, the companies are expected to pay attention to increasing the value of debt to assets ratio and return on assets to avoid the possibility of financial distress.
\end{abstract}

Keyword: financial distress; financial ratios; institutional ownership; managerial ownership.

\section{PENDAHULUAN}

Suatu perusahaan didirikan dengan tujuan memperoleh laba dari hasil produksi yang dilakukan. Namun dalam kegiatan operasional, perusahaan seringkali mengalami penurunan kinerja keuangan. Persaingan dan perubahan kondisi perekonomian pun juga bisa memengaruhi kinerja keuangan. Data dari Badan Pusat Statistik (BPS) menyampaikan laju pertumbuhan PDB tahunan di Indonesia sepanjang tahun 2018 mencapai 5,17\% yang berarti tertinggi dalam 4 tahun terakhir sejak tahun 2014 (Setkab.go.id, 2019). Pada tahun 2015 pertumbuhan ekonomi Indonesia menunjukkan angka terendah dibanding dengan data laju pertumbuhan 8 tahun terakhir, yaitu 4,88\% di mana hal itu menunjukkan adanya pertumbuhan ekonomi yang melambat. Melambatnya pertumbuhan ekonomi akan berdampak pada suatu perusahaan khususnya kinerja keuangan. Dalam hal ini, manajer diharapkan mampu mengelola dengan baik agar tidak sampai menghadapi kebangkrutan perusahaan. Karena kebangkrutan adalah bentuk bahaya dari financial distress. Hasil analisis laporan keuangan dipergunakan untuk mendapati kompetensi suatu perusahaan yang berkaitan (Hastuti \& Purwanto, 2015).

Perusahaan akan melakukan restrukturisasi atau bahkan sampai mengalami kebangkrutan karena masalah kesulitan yang dialami, kondisi inilah yang dimaksud dengan financial distress (Loman \& Malelak, 2015). Financial distress dapat terjadi dikarenakan ketidakmampuan perusahaan mengelolah serta memperhatikan konsistensi kemampuan finansial sehingga mengakibatkan suatu perusahaan mengalami rugi operasional hingga rugi bersih pada tahun berjalan (Santoso et al., 2018). Untuk melakukan penelitian, kriteria yang digunakan untuk mengetahui perusahaan yang menghadapi masalah keuangan ialah dengan Earning Per Share (EPS) negatif. Hasil dari data terkait EPS negatif periode 2015-2018 ditunjukkan pada gambar 1 berikut: 


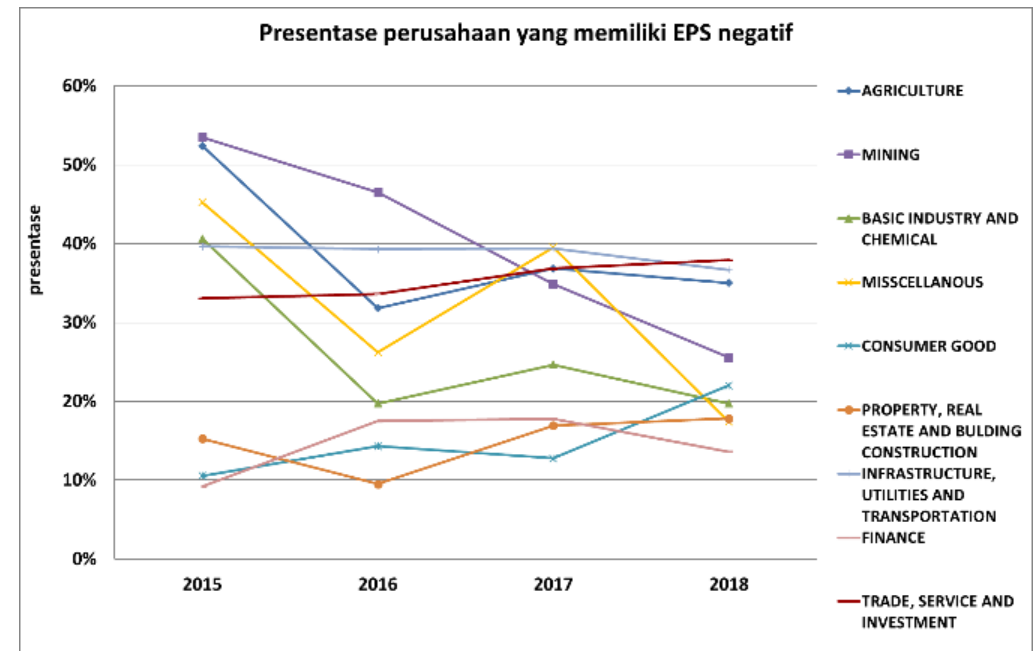

Sumber: www.idx.co.id, (2020, data diolah).

Gambar 1. PRESENTASE PERUSAHAAN YANG MEMILIKI EPS NEGATIF

Gambar 1 menunjukkan data dari Bursa Efek Indonesia yakni perusahaan tercatat dari semua sektor yang mengalami kenaikan nilai EPS atau bisa dikatakan memiliki EPS negatif selama berturut-turut adalah sektor Trade, Services, \& Investment. Itu berarti bahwa sektor tersebut mengalami penurunan keuntungan selama tahun 2015-2018. Semakin meningkatnya perusahaan sektor Trade, Services \& Investment menunjukkan adanya potensi perusahaan mengalami financial distress dengan kenaikan EPS negatif tiap tahunnya (Aini \& Purwohandoko, 2019).

Rasio keuangan dipergunakan pada penelitian ini untuk dijadikan evaluasi apa yang harus dilaksanakan ke depannya nanti agar kinerja manajemen suatu perusahaan dapat terus meningkat atau selalu dipertahankan sesuai dengan target dan tujuan yang telah ditentukan oleh suatu perusahaan (Kasmir, 2016:105). Rasio keuangan yang dipergunakan meliputi likuiditas, leverage, profitabilitas, serta aktivitas (Setiawan \& Amboningtyas, 2018).

Rasio likuiditas adalah kesanggupan perusahaan dalam melunasi liabilitas jangka pendek yang harus dipenuhi segera mungkin (Hidayat \& Meiranto, 2014). Proxy yang digunakan pada penelitian ini ialah current ratio. Hasil penelitian Pulungan et al. (2017) membuktikan current ratio berpengaruh signifikan positif terhadap financial distress. Sedangkan hasil penelitian yang menghasilkan pengaruh signifikan negatif current ratio terhadap financial distress yaitu (Pulungan et al., 2017). Penelitian lainnya membuktikan tidak adanya hubungan yang signifikan antara Current Ratio terhadap financial distress yaitu penelitian (Carolina et al., 2017).

Rasio leverage dipergunakan untuk menghitung seberapa banyak aset perusahaan didanai oleh utang (Kasmir, 2016:151). Menurut Sartono (2001) rasio yang dipergunakan untuk menghitung seberapa banyak perusahaan menggunakan utang sebagai modal untuk mendanai jalannya perusahaan adalah rasio leverage. Penelitian ini menggunakan Debt to Assets Ratio (DAR) sebagai gambaran rasio utang. Penelitian oleh Marota et al. (2018) memperlihatkan adanya pengaruh signifikan positif Debt to Assets Ratio terhadap financial distress. Sedangkan penelitian yang dilakukan oleh (Sari, 2015) memperlihatkan tidak ada pengaruh Debt to Assets Ratio terhadap financial distress.

Rasio profitabilitas merupakan kemampuan suatu perusahaan untuk memperoleh pendapatan di atas biaya-biaya yang diperhitungkan atau dalam kata lain yaitu bagaimana perusahaan mengelolah biaya (Ananto et al., 2017). Penelitian ini rasio profitabilitas yang digunakan adalah Return of Assets (ROA). Penelitian Carolina et al. (2017) memperlihatkan Return of Assets (ROA) berpengaruh signifikan positif terhadap financial distress. Perbedaan penelitian menyatakan bahwa Return of Assets (ROA) berpengaruh signifikan negatif terhadap financial distress yaitu (Damayanti et al., 2017). Penelitian 
Ainnun Masita \& Purwohandoko. Analisis Pengaruh Rasio Keuangan, Kepemilikan Manajerial, dan Kepemilikan Institusional terhadap Financial Distress pada Perusahaan Sektor Perdagangan, Jasa, dan Investasi yang Terdaftar di BEI Tahun 2015-2018

lainnya memperlihatkan bahwa terdapat hubungan yang tidak signifikan antar Return of Assets (ROA) dan financial distress yaitu penelitian (Simanjuntak et al., 2017).

Rasio aktivitas ialah rasio yang menilai seberapa efektif perusahaan dalam mengeksploitasi sumber daya yang dimiliki. Inventory, penagihan atas piutang, sales adalah bentuk dari efisiensi yang dilakukan perusahaan (Kasmir, 2016:172). Pada penelitian ini proxy yang digunakan ialah Total Assets Turn Over (TATO). Penelitian yang dilakukan (Noviandri, 2014) memperlihatkan pengaruh signifikan positif terhadap, penelitian (Widhiari \& Merkusiwati, 2015) menyatakan pengaruh signifikan negatif, dan penelitian lainnya menyatakan bahwa terdapat hubungan yang tidak signifikan antara Total Assets Turn Over (TATO) dan financial distress yaitu penelitian (Setiawan \& Amboningtyas, 2018).

Selain menggunakan rasio keuangan, kemungkinan terjadinya financial distress dapat diprediksi dengan faktor lain yang memengaruhi yaitu tata kelola yang diterapkan oleh perusahaan. Kepemilikan manajerial dan kepemilikan institusional merupakan komponen-komponen dalam tata kelola perusahaan. Kepemilikan manajerial yaitu kepemilikan saham pihak manajemen diantaranya direktur dan komisaris yang turun aktif dalam pengambilan keputusan perusahaan (Loman \& Malelak, 2015). Berbagai penelitian mengungkapkan tidak terdapat pengaruh kepemilikan manajerial terhadap financial distress (Loman \& Malelak, 2015). Namun penelitian oleh (Khairuddin et al., 2019) mengungkapkan bahwa kepemilikan manajerial berpengaruh signifikan positif terhadap financial distress).

Menurut Nora (2016), institusional ownership ialah perbandingan saham yang dipunyai pihak institusi atau organisasi atau badan usaha di suatu perusahaan. Penelitian Cinantya \& Merkusiwati (2015) memperlihatkan kepemilikan institusional memiliki pengaruh negatif. Namun penelitian Setiawan et al. (2017) mengatakan bahwa adanya pengaruh postif kepemilikan institusional terhadap financial distress.

Penelitian ini bertujuan untuk menganalisis pengaruh likuiditas, leverage, profitabilitas, aktivitas, kepemilikan manajerial, dan kepemilikan institusional terhadap financial distress pada perusahaan sektor perdagangan, jasa, dan investasi sebagai antisipasi atau early warning system sebelum terjadinya kondisi financial distress atau bahkan mengalami kebangkrutan.

\section{KAJIAN PUSTAKA DAN PENGEMBANGAN HIPOTESIS}

\section{Agency Theory}

Agency theory atau teori keagenan ini dicetuskan pertama kali oleh Jensen dan Meckling tahun 1951. Jensen dan Meckling (1976) mengungkapkan relasi keagenan merupakan sebuah perjanjian dua pihak yakni manajemen sebagai agen dan investor sebagai principal. Pada agency theory, akan muncul sebuah informasi asimetri antara manajemen dan investor dikarenakan terdapat ketidaksamaan keinginan antara keduanya yang berupaya untuk mencapai tujuan masing-masing. Informasi asimetri ini dapat menimbulkan konflik yang tentunya akan memunculkan biaya agen atau agency cost. Dengan adanya agency theory ini diharapkan keinginan antara manajemen dan investor menjadi selaras jadi agency cost bisa diturunkan (Setiyawan \& Musdholifah, 2020).

\section{Trade Off Theory}

Trade off theory ini menjelaskan mengenai upaya manajer untuk menaikkan nilai uang sampai pada satu titik di mana tambahan penambahan dana masalah keuangan telah mengimbangi nilai perlindungan pajak bunga tambahan (Brealey et al., 2008:18). Trade off theory pada struktur modal merupakan penyeimbang antara manfaat dan pengorbanan yang muncul dari pemanfaatan utang. Jika pengorbanan dalam pemanfaatan pinjaman bertambah besar, maka tidak perlu ada tambahan. Namun, jika manfaat yang diperoleh bertambah besar maka tambahan utang masih diperbolehkan (Priyatnasari \& Hartono, 2019). Besarnya utang yang dimiliki memungkinkan perusahaan mengalami penurunan laba bersih yang semakin besar, dan itu bisa menimbulkan perusahaan mengalami kesulitan dalam hal keuangan dan berpotensi mengalami kebangkrutan karena gagal bayar (Setiyawan \& Musdholifah, 2020). 


\section{Du Pont Theory}

Du pont theory ialah analisis yang memperlihatkan tingkat pengembalian atas aktiva yang diperoleh melalui perkalian profit margin dengan perputaran total aktiva (Brigham \& Houston, 2010:153). Menurut Priyatnasari \& Hartono (2019) analisis $d u$ pont ialah metode yang dapat dipergunakan untuk memperhitungkan efektivitas operasional perusahaan karena didalamnya terdapat unsur penjualan, aktivitas aktiva serta laba yang diperoleh. Perusahaan akan memperoleh laba tinggi ketika perusahaan dapat memaksimalkan penjualannya sehingga terjadi peningkatan kinerja perusahaan dan kecukupan dana bisa terjaga.

\section{Financial Distress}

Menurut Priyatnasari \& Hartono (2019) financial distress adalah situasi perusahaan menghadapi keuangan yang sulit sampai akhirnya menimbulkan likuidasi atau kebangkrutan. (Hanafi \& Halim, 2016) menyatakan bahwa kondisi keuangan yang sulit dalam waktu singkat itu sifatnya sementara, namun apabila tidak ada penanganan segera akan bisa menjadi kesulitan yang tidak solvabel atau utang tersebut lebih besar dari aset yang dimiliki dan cenderung pada kebangkrutan. Perusahaan diharapkan segera mengambil langkah cepat untuk mengatasi masalah keuangan agar tidak berakibat pada kebangkrutan.

Financial distress dapat diukur oleh berbagai upaya, salah satunya yaitu melihat Earning Per Share $(E P S)$. Upaya yang digunakan pada penelitian ini guna menilai keadaan perusahaan yang mengalami financial distress adalah dengan melihat Earning Per Share (EPS) yang bernilai negatif. Dari EPS dapat diketahui pendapatan bersih suatu perusahaan mengalami peningkatan atau penurunan yang mencerminkan kinerja perusahaan dan prospek pada masa yang akan datang. Skala pengukuran variabel ini menerapkan variabel dummy dengan pengukurannya yaitu $1(\mathrm{satu})=$ Distress, dan $0(\mathrm{nol})=$ Non Distress (Ekawati, 2016)

Metode yang digunakan untuk mendeteki kesulitan keuangan perusahaan (financial distress) ialah metode Altman Z-Score. Menurut Pulungan et al., (2017) metode Altman Z-Score ialah metode yang digunakan untuk memprediksi perusahaan mana yang memiliki kondisi keuangan yang sehat dan yang terancam menghadapi kepailitan. Metode ini menggabungkan beberapa rasio keuangan dan memberikan bobot yang berbeda pada masing-masing perusahaan. Menurut Sadida (2018) persamaan pada metode Altman Z-Score dapat dilihat di rumus (1).

$\mathrm{Z}=6.56 X^{1}+3.26 X^{2}+6.72 X^{3}+1.05 X^{4}$

Keterangan:

$\mathrm{X}^{1} \quad=$ Working capital/total assets

$\mathrm{X}^{2} \quad=$ Retained earnings/total assets

$\mathrm{X}^{3} \quad=$ Earnings before interest and taxes/total assets

$\mathrm{X}^{4} \quad=$ Book value of equity/total liabilities

Klasifikasi untuk persamaan metode Altman Z-Score apabila perusahaan mempunyai nilai Z $<1.1$ mengindikasikan bahwa perusahaan mengalami financial distress dan diberi angka 1. Sedangkan apabila nilai $\mathrm{Z}>1.1$ mengindikasikan bahwa perusahaan tidak mengalami financial distress dan diberi angka 0 (Ananto et al., 2017).

\section{Likuiditas}

Likuiditas ialah kesanggupan perusahaan menjual aset guna untuk mendapatkan kas pada waktu singkat (Brealey et al., 2008). Proxy yang digunakan adalah current ratio, yang dipergunakan untuk menilai kesanggupan perusahaan untuk memenuhi kewajiban jangka pendek secara keseluruhan pada saat ditagih (jatuh tempo). Jika nilai rasio lancar rendah menunjukkan tingginya risiko likuiditas, dan jika nilainya tinggi maka menunjukkan lebihnya aset lancar yang berpengaruh buruk pada profit perusahaan (Hanafi \& Halim, 2016). Menurut Hastuti \& Purwanto (2015) Current Ratio diformulasikan dengan rumus (2). 
Ainnun Masita \& Purwohandoko. Analisis Pengaruh Rasio Keuangan, Kepemilikan Manajerial, dan Kepemilikan Institusional terhadap Financial Distress pada Perusahaan Sektor Perdagangan, Jasa, dan Investasi yang Terdaftar di BEI Tahun 2015-2018

Current Ratio $=\frac{\text { Current Assets }}{\text { Current Liabilities }}$

\section{Leverage}

Leverage ialah rasio untuk menghitung besarnya hutang jangka pendek maupun hutang jangka panjang yang dimiliki oleh perusahaan (Hidayat \& Meiranto, 2014). Proxy yang digunakan pada rasio leverage ini adalah Debt to Assets Ratio. DAR dipergunakan untuk mengukur seberapa besar aktiva perusahaan didanai oleh hutang dengan cara membandingkan total hutang dengan total aktiva (Kasmir, 2010), diformulasikan dengan rumus (3).

Debt to Assets Ratio $=\frac{\text { Total Hutang }}{\text { Total Aktiva }}$

\section{Profitabilitas}

Menurut Kasmir (2010) rasio profitabilitas ialah rasio yang digunakan untuk memperkirakan kesanggupan perusahaan dalam mendapatkan profit. Rasio ini dapat memberikan skala tingkat efektivitas manajemen suatu perusahaan. Proxy dalam penelitian ini adalah Return On Assets (ROA), di mana rasio ini dipergunakan untuk menilai kesanggupan perusahaan dalam memperoleh net profit yang bersumber pada peningkatan aset yang digunakan perusahaan. ROA yang tinggi dapat menunjukkan daya guna manajemen dalam mengatur investasinya. ROA menurut Sari (2015) diformulasikan dengan rumus (4).

Return on Assets $=\frac{E B I T}{\text { Total Assets }}$

\section{Aktivitas}

Menurut Kasmir (2010:115) rasio aktivitas adalah rasio yang dipergunakan untuk menilai efekivitas perusahaan dalam penggunaan aktiva yang dimiliki perusahaan, atau bisa dikatakan rasio ini dipergunakan untuk menilai efisiensi penggunaan sumber daya yang dimiliki perusahaan. Dalam penelitian ini proksi yang digunakan yaitu TATO, ialah dipergunakan untuk memperkirakan seberapa efektif perusahaan memanfaatkan sumber daya berupa aset (Noviandri, 2014). Tingginya rasio ini berarti semakin tinggi efektivitas pemanfaatan aset dan pengambilan dana dalam bentuk kas juga semakin cepat. Menurut Noviandri (2014) TATO diformulasikan dengan rumus (5).

$$
\text { TATO }=\frac{\text { Sales }}{\text { Total Assets }}
$$

\section{Kepemilikan Manajerial}

Kepemilikan manajerial ialah proporsi saham oleh manajemen yang dimiliki dari seluruh jumlah saham yang ada di perusahaan tersebut (Setiawan et al., 2017). Adanya rasa memiliki yang tinggi terhadap saham suatu perusahaan ini dapat menjadikan nilai tambah tersendiri bagi perusahaan terkait dengan kepemilikan saham manajerial. Dengan begitu, manajer tentunya mempunyai lebih banyak informasi karena berada dalam operasional perusahaan. Menurut Khairuddin et al., (2019) kepemilikan manajerial diformulasikan dengan rumus (6).

Kep. Manajerial $=\frac{\text { jumlah saham yang dimiliki manajemen }}{\text { Total Saham Beredar }} \times 100 \%$

\section{Kepemilikan Institusional}

Kepemilikan institusional ialah proporsi saham oleh institusi yang dimiliki dari seluruh jumlah saham di perusahaan, tidak termasuk bank (Setiawan et al., 2017). Institusi yang dimaksud seperti bank dan yayasan. Adanya saham institusi ini menjadikan investor institusi dapat memonitor apa yang dilakukan oleh manajemen. tingginya kepemilikan institusional ini kemungkinan perusahaan menggunakan utang sebagai sumber pendanaan juga semakin menurun. Menurut Khairuddin et al., (2019) kepemilikan institusional dapat diformulasikan dengan rumus (7).

Kep. Institusional $=\frac{\text { jumlah } \text { saham yang dimiliki institusi }}{\text { Total Saham Beredar }} \times 100 \%$ 


\section{Hubungan antar Variabel}

Current Ratio ini memperlihatkan seberapa besar kesanggupan perusahaan melunasi hutang lancar ketika jatuh tempo atau ketika ditagih. Apabila ketika perusahaan tidak dapat melunasi kewajibannya maka perusahaan berpotensi mengalami financial distress akan bertambah tinggi. Begitu juga sebaliknya, jika perusahaan mampu membayar kewajibannya maka potensi terjadinya financial distress menurun (Pulungan et al., 2017).

\section{H1: Current Ratio berpengaruh positif terhadap financial distress.}

Debt to Assets Ratio digunakan untuk menilai kemampuan perusahaan membayar semua kewajibannya (jangka pendek dan jangka panjang). Apabila perusahaan memiliki pendanaan yang lebih banyak oleh hutang maka hal itu akan berimbas pada keharusan untuk membalikkan pinjaman serta bunganya (Yustika, 2015). Tingginya hutang dan beban bunga yang harus dibayarkan akan membuat perusahaan mengalami gagal bayar. Jika nilai rasio semakin besar maka menunjukkan lebih banyak perusahaan menggunakan hutang, di mana hal ini mengindikasikan bahwa perusahaan berpotensi mengalami kesulitan keuangan (Priyatnasari \& Hartono, 2019).

\section{H2: Debt to Assets Ratio berpengaruh positif terhadap financial distress.}

Return On Assets ini menunjukkan baik buruknya kondisi kinerja perusahaan yang dinilai dari perolehan laba dari hasil pendapatan investasi dan operasi perusahaan (Curry \& Banjarnahor, 2018). Perusahaan yang mempunyai nilai ROA tinggi menandakan perolehan laba yang didapat pun menunjukkan kinerja yang baik, sehingga perusahaan terhindar dari kesulitan keuangan. Melainkan perusahaan memiliki nilai ROA yang rendah maka perusahaan dapat dikatakan mengalami financial distress karena kinerja perusahaan pun juga ikut menurun (Carolina et al., 2017).

\section{H3: Return On Assets berpengaruh positif terhadap financial distress.}

TATO ialah rasio yang digunakan untuk menilai efisiensi penggunaan aktiva secara keseluruhan. Apabila nilai dari rasio ini rendah maka dapat dikatakan adanya penurunan yang cukup besar dalam pengunaan aset sehingga pengembalian dana pun juga lambat (Noviandri, 2014). Manajemen yang tidak bisa memaksimalkan penggunaan asetnya akan mengakibatkan penjualan pun tidak maksimal dan hal itu menjadikan perusahaan terancam mengalami financial distress (Hidayat \& Meiranto, 2014).

\section{H4 : TATO berpengaruh positif terhadap financial distress.}

Kepemilikan manajerial adalah kepemilikan saham oleh beberapa orang yang berasal dari internal perusahaan (Setiawan et al., 2017). Adanya kepemilikan yang besar diharapkan dapat menurunkan terjadinya kesulitan keuangan perusahaan. Hal itu terjadi sebab semakin besar kepemilikan manajerial akan mampu mempersatukan keinginan manajer dan pemegang saham. Begitu sebaliknya jika kepemilikan manajerial kecil maka informasi asimetris antara manajer dan pemegang saham akan terjadi. Informasi asimetris ini dapat memicu timbulnya biaya keagenan sehingga potensi perusahaan mengalami financial distress pun pasti ada (Fathonah, 2017).

H5 : Kepemilikan manajerial berpengaruh positif terhadap financial distress.

Kepemilikan institusional ialah kepemilikan saham oleh institusi, bukan kepemilikan investor individu. Besarnya kepemilikan institusional menandakan pengawasan terhadap perusahaan juga semakin besar. Apabila kepemilikan saham oleh institusi ini sedikit maka itu membuat pengawasan pun menurun (Khairuddin et al., 2019). Penurunan itu mengarah pada kinerja perusahaan yang ikut menurun, di mana hal itu akan mengakibatkan perusahaan mengalami financial distress.

H6 : Kepemilikan institusional berpengaruh positif terhadap financial distress 
Ainnun Masita \& Purwohandoko. Analisis Pengaruh Rasio Keuangan, Kepemilikan Manajerial, dan Kepemilikan Institusional terhadap Financial Distress pada Perusahaan Sektor Perdagangan, Jasa, dan Investasi yang Terdaftar di BEI Tahun 2015-2018

\section{METODE PENELITIAN}

Jenis penelitian ini adalah penelitian konklusif dan kausal. Data yang digunakan ialah data kuantitatif, dan sumber data yang digunakan ialah data sekunder di mana perolehan datanya dari website www.idx.co.id atau website tiap perusahaan berupa laporan keuangan dan laporan tahunan. Populasi yang digunakan ialah semua perusahaan sektor perdagangan, jasa dan investasi yang terdaftar di BEI periode 2015-2018. Metode pengambilan sampel ialah purposive sampling, berdasarkan kriteria penentuan sesuai topik penelitian yaitu seperti berikut. (1) perusahaan sektor yang konsisten melaporkan laporan tahunan selama periode tahun 2015-2018; (2) perusahaan yang memiliki EPS negatif selama dua tahun berturut-turut; (3) perusahaan yang mempunyai kelengkapan data terkait variabel-variabel yang dibutuhkan periode tahun 2015-2018. Berdasarkan kriteria tersebut, perusahaan yang dijadikan sampel penelitian berjumlah 15 perusahaan.

\section{HASIL DAN PEMBAHASAN}

\section{Statistik Deskriptif}

Statistik deskriptif pada penelitian ini menjelaskan sampel secara spesifik mulai dari jumlah sampel $(\mathrm{N})$, nilai minimum (min), nilai maksimum (max), nilai rata-rata (mean), dan nilai standart deviasi (Std. Deviation) dari tiap-tiap variabel. Apabila nilai mean lebih rendah dari satandart deviasi ini bermakna terdapat penyimpangan data yang tinggi. Hasil statistik deskriptif ditunjukkan pada tabel 1 berikut:

Tabel 1.

\section{DESCRIPTIVE STATISTICS}

\begin{tabular}{llcccc}
\hline Variabel & $\mathbf{N}$ & Min & Max & Mean & Std. Dev \\
\hline FD & 60 & 0 & 1 & .55 & .502 \\
CR & 60 & .19 & 1211.99 & 135.3439 & 234.75321 \\
DAR & 60 & 5.20 & 192.28 & 60.9261 & 37.66225 \\
ROA & 60 & -28.66 & 8.87 & -1.6847 & 6.26167 \\
TATO & 60 & .00 & 540.73 & 81.2816 & 117.88704 \\
KEP.MAN & 60 & .00 & 31.4 & 3.6152 & 6.60135 \\
KEP.INS & 60 & 13.86 & 97.55 & 67.1411 & 20.22548 \\
Valid N & 60 & & & & \\
\hline
\end{tabular}

Sumber: SPSS (2020, data diolah)

\section{Overall Model Fit}

Pengujian ini dipergunakan untuk menguji hipotesis dengan data telah fit atau tidak. Dalam arti lain, uji ini dilakukan dengan tujuan melihat apakah model dapat diperbaiki atau tidak ketika ada tambahan variabel bebas ke dalam model. Hasil pengujian yang ditunjukan dengan nilai -2Log Likelihood yang terdiri hanya konstanta ialah sejumlah 88.577, dan ketika dimasukkan variabel bebas sebesar 22.003. Hal ini menunjukkan adanya penurunan sebesar 60.574 dan jika dilihat dengan menggunakan chi square tabel dengan df7 (55-49) maka diperoleh nilai sebesar 12.592. Penurunan -2Log likelihood ini relevan secara statistik, sehingga model dapat diperbaiki dengan adanya tambahan variabel bebas ke dalamnya.

\section{Nagelkerke's $R$ Square}

Nagelkerke's $R$ Square atau koefisien determinasi dipergunakan untuk mengukur besarnya variabel independen dalam menggambarkan variabel dependen. Hasil penelitian memperlihatkan nilai Nagelkerke's $R$ Square sebesar 0.850 atau $85 \%$, ini bermakna variabel dependen mampu digambarkan variabel independen dengan besar persentase $85 \%, 15 \%$ sisanya digambarkan dengan variabel-variabel lain di luar model. 


\section{Hosmer and Lemeshow's Goodness of Fit}

Uji Hosmer and Lemeshow's Goodness of Fit merupakan uji untuk menilai kelayakan model regresi apakah ada kecocokan antara data empiris dengan model. Hasil pengujian menunjukkan nilai chi square 0.476 dengan signifikansi 1.000, maka $\mathrm{H} 0$ diterima karena nilai signifikansi dari hasil tersebut $>0.05$. Artinya, model dengan nilai observasinya tidak terdapat perbedaan atau dapat menerima model.

\section{Tabel Klasifikasi}

Tabel klasifikasi ini digunakan untuk mengetahui nilai perkiraan dalam menggolongkan perusahaan ke kategori distress dan non distress. Tabel 2 memperlihatkan hasil pengujian tabel klasifikasi. Perusahaan yang non distress terlihat pada kolom observed sebanyak 27 dan perusahaan mengalami distress sebanyak 33. Pada kolom predicted perusahaan yang non distress sebanyak 24 dengan perolehan ketepatan klasifikasi sebesar 88.9\% (24/27), dan untuk perusahaan mengalami distress sebanyak 30 dengan akurasi klasifikasi diperoleh 90.9\% (30/33). Jadi secara menyeluruh akurasi prediksi klasifikasi yaitu sebesar $90.0 \%$.

Tabel 2.

TABEL KLASIFIKASI

\begin{tabular}{|c|c|c|c|c|}
\hline & \multirow{2}{*}{ Observed } & \multicolumn{2}{|c|}{ Predicted FD } & \multirow{2}{*}{ Percentage Correct } \\
\hline & & Non Distress & Distress & \\
\hline \multirow{3}{*}{$\overline{\text { Step } 3}$} & \multirow{2}{*}{ FD distress } & 24 & 3 & 88.9 \\
\hline & & 3 & 30 & 90.9 \\
\hline & Overall Percentage & & & 90.0 \\
\hline
\end{tabular}

Sumber: SPSS (2020, data diolah)

\section{Estimasi Parameter dan Interpretasinya}

Uji hipotesis ini menguji variabel current ratio $(C R)$, debt to assets ratio $(D A R)$, return on assets (ROA), total assets turnover (TATO), kepemilikan manajerial serta kepemilikan institusional dalam memprediksi pengaruhnya terhadap financial distress. Uji regresi logistik digunakan pada pengujian ini dan ditunjukkan oleh tabel variables in the equation, pada kolom signifikan 0.05 atau 5\%. Tingkat signifikansi $<0.05$ berarti Ha diterima atau dapat dikatakan variabel tersebut berpengaruh terhadap financial distress. Hasil uji regresi logistik pada tabel 3 menghasilkan model (8).

$\operatorname{Ln} \frac{P}{1-P}=-20.924+0.203 \mathrm{DAR}-0.307 \mathrm{ROA}+\mathrm{e}$.

Tabel 3.

VARIABLES IN THE EQUATION

\begin{tabular}{lccc}
\hline & Keterangan & B & Sig. \\
\hline${\text { Step } 3^{\mathrm{a}}}$ & DAR & .203 & .012 \\
& ROA & -.307 & .021 \\
& KEP.MAN & .745 & .071 \\
& KEP.INS & .073 & .162 \\
& Constant & -20.924 & .023 \\
\hline
\end{tabular}

Sumber: SPSS (2020, data diolah)

\section{Pengaruh Current Ratio terhadap Financial Distress}

Hasil pengujian memperlihatkan bahwa current ratio tidak berpengaruh terhadap financial distress. Hasil penelitian ini selaras dengan penelitian yang dilakukan oleh (Hafizah, 2015; Simanjuntak et al., 2017) yang menyatakan current ratio tidak berpengaruh terhadap financial distress. Tidak adanya pengaruh current ratio ini diakibatkan karena banyak faktor, salah satunya elemen pembentuk aset lancar ialah akun piutang usaha dan akun persediaan yang jika dipergunakan untuk melunasi kewajiban jangka pendek tentunya butuh waktu yang panjang. Piutang dan kas yang tinggi menandakan bahwa perusahaan telah melakukan penjualan yang tinggi pula, tingginya penjualan mengindikasikan laba 
Ainnun Masita \& Purwohandoko. Analisis Pengaruh Rasio Keuangan, Kepemilikan Manajerial, dan Kepemilikan Institusional terhadap Financial Distress pada Perusahaan Sektor Perdagangan, Jasa, dan Investasi yang Terdaftar di BEI Tahun 2015-2018

yang dimiliki perusahaan pun juga tinggi sehingga bisa digunakan untuk melunasi kewajiban jangka pendeknya, dengan begitu akan semakin rendah kemungkinan perusahaan menghadapi financial distress (Nora, 2016).

Berdasarkan data perusahaan INTA pada tahun 2015-2018 yang memiliki nilai current ratio variatif mengalami kondisi financial distress. Tahun 2015 sebesar $0.86 \%$, tahun 2016 sebesar $87.53 \%$, tahun 2017 sebesar $75.47 \%$, dan tahun 2018 sebesar $121.65 \%$. Berbeda dengan perusahaan OKAS yang mengalami kenaikan current ratio tiap tahunnya namun mengalami kondisi financial distress. Hal ini menunjukkan besar atau kecilnya nilai current ratio tidak membuat perusahaan tersebut terhindar dari kondisi financial distress, ini dikarenakan ketika nilai aset lancar naik, bisa jadi nilai hutang lancar pun juga semakin naik, semakin turun atau tetap stabil.

Penelitian ini tidak mampu mendukung trade off theory yang menjelaskan bahwa perusahaan akan diuntungkan dengan hematnya biaya pajak atas tambahan utang yang dilakukan. Penambahan utang yang dilakukan perusahaan secara berkelanjutan dapat mengakibatkan tingginya beban bunga yang harus ditanggung. Hal ini memungkinkan perusahaan mengalami penurunan laba bersih yang bisa menimbulkan kesulitan keuangan dan potensi mengalami kebangkrutan karena gagal bayar. Implikasi praktis dari hasil temuan ini, perusahaan sektor perdagangan, jasa, dan investasi tidak harus meningkatkan nilai current ratio karena kenaikan current ratio tidak mampu menurunkan perusahaan mengalami financial distress. Perusahaan sebaiknya mempertimbangkan faktor lain yang mampu untuk melunasi kewajiban jangka pendek dalam waktu yang cepat, yaitu meningkatkan akun aset lancar dalam bentuk tunai.

\section{Pengaruh Debt to Assets Ratio terhadap Financial Distress}

Berdasarkan hasil pengujian, memperlihatkan bahwa debt to assets ratio berpengaruh positif terhadap financial distress. Hasil penelitian ini selaras dengan penelitian yang dilakukan oleh (Damayanti et al., 2017; Vinh, 2015) yang menyatakan bahwa ada pengaruh positif debt to assets ratio terhadap financial distress.Perusahaan yang mempunyai hutang yang besar berarti beban yang ditanggung juga semakin besar, sehingga risiko gagal bayar juga semakin besar dan perusahaan akan mengalami financial distress. Perusahaan besar lebih sering menggunakan hutang dalam jumlah besar dalam mengelola perusahaan di mana keuntungan yang didapat pun juga besar. Semakin meningkat nilai DAR maka semakin meningkat pula kemungkinan perusahaan mengalami financial distress (Damayanti et al., 2017).

Data yang mendukung hasil penelitian ini yaitu perusahaan RIMO pada rentan tahun 2015-2018, memiliki nilai debt to assets ratio yang paling rendah pada tahun 2015 yaitu sebesar $5.20 \%$ dan tergolong ke dalam perusahaan yang mengalami financial distress. Sedangkan perusahaan BNBR pada rentan tahun 2015-2018 memiliki nilai debt to assets ratio paling tinggi pada tahun 2016 yaitu sebesar $192.28 \%$ dan tergolong perusahaan tidak mengalami financial distress. Dari penjelasan data tersebut, nilai debt to assets ratio yang tinggi akan meningkatkan kondisi perusahaan mengalami financial distress dan nilai debt to assets ratio yang rendah akan menurunkan kondisi perusahaan mengalami financial distress.

Penelitian ini mendukung trade off theory yang menjelaskan mengenai struktur modal dalam suatu perusahaan. Teori struktur modal merupakan penyeimbang antara manfaat dan pengorbanan yang timbul karena penggunaan hutang. Pertukaran keuntungan penghematan pajak dengan menambah hutang akan menimbulkan perusahaan mengalami kesulitan keuangan. Implikasi praktis dari hasil penelitian ini, perusahaan sektor perdagangan, jasa, dan investasi harus memperhatikan peningkatan nilai debt to assets ratio karena debt to assets ratio dapat menurunkan kondisi financial distress pada perusahaan. Hal itu juga ditunjang dengan pemanfaatan hutang yang maksimal pada penambahan hutang yang dilakukan, agar perusahaan memperoleh keuntungan yang maksimal pula dari hutang tersebut. 


\section{Pengaruh Return On Assets terhadap Financial Distress}

Berdasarkan hasil pengujian memperlihatkan bahwa return on assets berpengaruh negatif terhadap financial distress. Hasil penelitian ini selaras dengan penelitian yang dilakukan oleh (Alifiah, 2014; Ayu et al., 2017; Damayanti et al., 2017) yang menyatakan bahwa ada pengaruh negatif return on assets terhadap financial distress. Nilai return on assets yang besar menunjukkan perusahaan dalam mengelola aset yang dimiliki akan semakin baik, sehingga terjadinya financial distress semakin rendah. Apabila nilai return on assets rendah maka perusahaan dalam mengelolah asetnya tidak efektif sehingga kemungkinan perusahaan menghadapi financial distress akan semakin besar. Perusahaan sektor perdaganga, jasa, dan investasi yang mengalami financial distress dominan memiliki nilai return on assets negatif.

Berdasarkan data perusahaan HOME pada tahun 2015-2017 terhindar dari kemungkinan financial distress dengan rasio return on assets bernilai positif yaitu sebesar $1.32 \%$ pada tahun $2015,1.00 \%$ pada tahun 2016, dan 2.20\% pada tahun 2017. Sedangkan pada tahun 2018 termasuk dalam kategori mengalami financial distress dengan nilai return on assets negatif yaitu sebesar $-7.03 \%$. Berdasarkan penjelasan tersebut, nilai return on assets yang tinggi dapat menurunkan kemungkinan terjadinya financial distress, dan nilai return on assets yang rendah dapat meningkatkan terjadinya financial distresss.

Penelitian ini mampu mendukung teori $d u$ pont, yang menerangkan mengenai keterkaitan tingkat pengembalian aset dan profit margin. Kemampuan perusahaan dalam mendapatkan profit margin dari pengembalian aset menunjukkan tingginya penerimaan arus kas masuk oleh perusahaan, sehingga perusahaan dapat dikatakan berada pada kondisi keuangan yang baik. Hal ini tentunya bisa menurunkan peluang perusahaan mengalami financial distress (Priyatnasari \& Hartono, 2019). Implikasi praktis dari hasil penelitian ini ialah perusahaan sektor perdagangan, jasa, dam investasi harus memperhatikan kenaikan tingkat nilai return on assets karena besarnya nilai return on assets dapat menurunkan keungkinan terjadinya financial distress. Hal yang perlu diperhatikan perusahaan sektor perdagangan, jasa, dan invstasi yaitu pengupayaan dalam perolehan laba yang tinggi.

\section{Pengaruh Total Assets Turnover terhadap Financial Distress}

Berdasarkan hasil pengujian dengan menggunakan regresi logistik didapatkan hasil total assets turnover tidak ada pengaruh terhadap financial distress. Hasil penelitian ini selaras dengan penelitian yang dilakukan oleh (Nora, 2016; Sean \& Viriany, 2016) yang menyatakan bahwa total assets turnover tidak berpengaruh terhadap financial distress. Tidak adanya pengaruh total assets turnover ini diakibatkan karena adanya pengeluaran yang dikeluarkan tidak sebanding dengan laba yang diperoleh. Di mana peningkatan penjualan dan menurunnya biaya yang dikeluarkan ini menandakan adanya keuntungan yang diperoleh meningkat, sehingga total assets turnover pun meningkat (Nora, 2016). Namun jika perusahaan tidak mampu, ini berarti laba yang diperoleh pun akan menurun sehingga dapat dikatakan penjualan tidak mampu memengaruhi financial distress.

Data yang mendukung hasil penelitian ini adalah perusahaan ABBA yang memiliki nilai total assets turnover menurun tiap tahunnya dari tahun 2015-2018 dan mengalami financial distress tiap tahunnya. Dari data lain perbandingan antara perusahaan RIMO dan BMSR pada tahun 2017 di mana perusahaan RIMO memiliki nilai total assets turnover yang paling rendah yaitu sebesar $4.78 \%$ dan terindikasi tidak mengalami financial distress, dan perusahaan BMSR memiliki nilai total assets turnover yang paling tinggi yaitu sebesar 520.27\% yang terindikasi mengalami financial distress. Dari penjelasan di atas, besar kecilnya nilai total assets turnover tidak berpengaruh terhadap financial distress.

Penelitian ini tidak mampu mendukung $d u$ pont theory yang menjelaskan bahwa perusahaan tentu mendapatkan keuntungan yang tinggi ketika perusahaan dapat memaksimalkan penjualannya, sehingga kinerja perusahaan meningkat dan kecukupan dana akan terjaga. Tingginya nilai total assets turnover berarti bahwa perusahaan mengalami peningkatan dalam penjualan yang menyebabkan laba perusahaan pun tinggi sehingga kinerja perusahaan meningkat dan perusahaan akan terhindar dari financial distress. Implikasi praktis dari penelitian ini, perusahaan sektor perdagangan, jasa, dan investasi tidak harus 
Ainnun Masita \& Purwohandoko. Analisis Pengaruh Rasio Keuangan, Kepemilikan Manajerial, dan Kepemilikan Institusional terhadap Financial Distress pada Perusahaan Sektor Perdagangan, Jasa, dan Investasi yang Terdaftar di BEI Tahun 2015-2018

memperhatikan peningkatan nilai TATO karena bahwa besar kecilnya nilai TATO tidak berpengaruh terhadap financial distress. Perusahaan harus berupaya untuk melakukan efisiensi biaya pada tiap penjualan agar didapatkan keuntungan yang tinggi dibanding dengan biaya yang dikeluarkan.

\section{Pengaruh Kepemilikan Manajerial terhadap Financial Distress}

Berdasarkan hasil pengujian didapatkan hasil bahwa kepemilikan manajerial tidak berpengaruh terhadap financial distress. Hasil penelitian ini selaras dengan penelitian yang dilakukan oleh (Cinantya \& Merkusiwati, 2015; John \& Ogechukwu, 2018) yang menyatakan bahwa kepemilikan manajerial tidak berpengaruh terhadap financial distress. Hal ini dikarenakan masih banyaknya perusahaan yang tidak menerapkan kebijakan untuk memiliki saham perusahaan bagi pihak manajemen perusahaan tersebut. Pada perusahaan yang menjadi sampel, terdapat sekiranya hanya satu data mengenai kepemilikan manajerial dalam jumlah tahun penelitian yang dilakukan.

Data yang mendukung hasil penelitian ini adalah perusahaan DYAN, yang memiliki kepemilikan manajerial tiap tahunnya yaitu dari tahun 2015-2018. Pada tahun 2015-2016 perusahaan mengalami financial distress, namun tahun 2017-2018 tidak mengalami financial distress. Meskipun tingkat presentase kepemilikan manajerial pada tahun 2015 ini lebih tinggi dibanding dengan tahun 2016-2018 yaitu sebesar 10.44, akan tetapi perusahaan ini mengalami financial distress. Sehingga dari penjelasan data dapat disimpulkan bahwa kepemilikan manajerial tidak berpengaruh terhadap financial distress.

Penelitian ini tidak mampu mendukung agency theory, menjelaskan bahwa kepemilikan manajerial dapat menurunkan agency cost karena adanya keselarasan kepentingan antara agen dan principal. Menurut Damayanti et al. (2017). Manajer akan cenderung menggunakan sumber daya secara berlebihan ketika biaya keagenan yang dimiliki perusahaan ini besar, yang mana jika terjadi secara berkelanjutan akan menyebabkan menurunnya keuangan perusahaan sehingga terjadinya financial distress meningkat. Implikasi praktis dari hasil penelitian ini yakni perusahaan sektor perdagangan, jasa, dan investasi tidak harus memperhatikan tingginya kepemilikan manajerial pada suatu perusahaan karena kepemlikan manajerial yang tinggi tidak dapat menurunkan kondisi kesulitan keuangan perusahaan, ini disebabkan tidak semua perusahaan memiliki kepemilikan manajerial. Upaya yang bisa dilakukan perusahaan adalah dengan menerapkan kebijakan kepada pihak manajemen untuk memiliki saham pada perusahaan.

\section{Pengaruh Kepemilikan Institusional terhadap Financial distress}

Berdasarkan hasil pengujian, didapatkan bahwa tidak terdapat pengaruh antara kepemilikan institusional dengan financial distress. Hasil penelitian ini selaras dengan penelitian yang dilakukan oleh (Nora, 2016; Santoso et al., 2018) yang menyatakan bahwa kepemilikan institusional tidak berpengaruh terhadap financial distress. Hal ini disebabkan kepemilikan saham oleh instansi besar kepemilikannya terpusat dan tidak menyebar, sehingga menyebabkan pengawasan oleh pemegang saham terhadap manajemen pun akan menurun. Dengan begitu kemampuan pemegang saham untuk mengendalikan manajemen dalam mengelolah perusahaan tidaklah cukup, sehingga memungkinkan manajemen untuk mengambil keputusan sesuai dengan keinginannya (Kurniasanti \& Musdholifah, 2018). Tidak hanya itu, dalam praktiknya pemegang saham tidak menjalankan perannya dengan baik dalam hal monitoring tindakan pihak manajemen.

Data yang mendukung hasil penelitian ini adalah perusahaan BMSR yang memiliki nilai kepemilikan institusional yang sama pada tahun 2015-2017 yaitu sebesar $87.55 \%$ tidak mengalami financial distress pada tahun 2015-2016, sedangkan pada tahun 2017 mengalami financial distress. Hal ini berarti bahwa besar kecilnya kepemilikan oleh manajerial tidak bisa menunjukkan perusahaan mengalami financial distress. Sehingga dari penjelasan data dapat disimpulkan bahwa kepemilikan institusional tidak berpengaruh terhadap financial distress yang dialami perusahaan.

Penelitian ini tidak mampu mendukung agency theory, menerangkan bahwa kepemilikan institusional adalah salah satu konsep good corporate governance yang bisa digunakan untuk menghindari informasi asimetri antara manajemen dan pemegang saham. Adanya kepemilikan institusional yang menurun 
maka kinerja perusahaan pun juga menurun karena kurangnya pengawasan dari pemegang saham, sehingga perusahaan akan mengalami kesulitan keuangan. Implikasi praktis dari hasil penelitian ini yakni perusahaan sektor perdagangan, jasa, dan investasi tidak harus memperhatikan tingginya kepemilikan institusional pada suatu perusahaan karena besar kecilnya kepemilikan saham oleh institusi tidak dapat menurunkan kondisi financial distress. Perusahaan bisa melakukan usaha yaitu dengan memastikan bahwa pemegang saham benar-benar telah menjalankan perannya dengan baik dalam hal monitoring.

\section{KESIMPULAN}

Berdasarkan uraian hasil analisis maka kesimpulan yang dapat diambil ialah terdapat dua variabel independen yang memiliki pengaruh terhadap financial distress diantaranya debt to assets ratio yang mempunyai pengaruh positif dan return on assets yang mempunyai pengaruh negatif. Leverage berpengaruh positif terhadap financial distress ditunjukkan dengan nilai debt to assets ratio yang tinggi akan meningkatkan kondisi terjadi financial distress dan nilai debt to assets ratio yang rendah akan menurunkan kondisi terjadinya financial distress. Pengaruh negatif profitabilitas terhadap financial distress menandakan bahwa semakin besar nilai return on assets semakin baik juga perusahaan mengelolah aset yang dimiliki. Pengelolaan perusahaan yang baik ditunjukkan dengan terjaganya dana yang cukup dalam perusahaan, sehingga terjadinya financial distress semakin kecil.

Penelitian ini memiliki keterbatasan mulai dari populasi, tahun penelitian, variabel independen yang digunakan, hingga ukuran dalam menggambarkan financial distress. Bagi peneliti berikutnya diharapkan menambah beberapa sektor perusahaan lainnya dan jumlah tahun penelitian, agar data dalam penelitian lebih banyak, sehingga dapat meningkatkan keakuratan hasil penelitian. Selain itu, peneliti berikutnya diharapkan menambah variabel lain selain pada penelitian ini misalnya sales growth, firm size, dan inflation, serta memakai ukuran lain dalam menggambarkan perusahaan yang mengalami financial distress.

\section{DAFTAR PUSTAKA}

Aini, D. Q., \& Purwohandoko. (2019). Pengaruh Rasio Likuiditas, Leverage, Aktivitas, Profitabilitas dan Sales Growth Terhadap Financial Distress (Studi Kasus pada Perusahaan Sektor Pertambangan yang Terdaftar di Bursa Efek Indonesia Periode 2012-2016). Jurnal Ilmu Manajemen (JIM), 7(2), 372-381.

Alifiah, M. N. (2014). Prediction of Financial Distress Companies in the Trading and Services Sector in Malaysia Using Macroeconomic Variables. Procedia - Social and Behavioral Sciences, 129, 90-98. https://doi.org/10.1016/j.sbspro.2014.03.652

Ananto, R. P., Mustika, R., \& Handayani, D. (2017). Pengaruh Good Corporate Governance (GCG), Leverage, Profitabilitas dan Ukuran Perusahaan Terhadap Financial Distress pada Perusahaan Barang Konsumsi yang Terdaftar Di Bursa Efek Indonesia. Jurnal Ekonomi \& Bisnis Dharma Andalas, 19(1), 92-105.

Ayu, A., Handayani, S., \& Topowijono, T. (2017). Pengaruh Likuiditas, Leverage, Profitabilitas, dan Ukuran perusahaan Terhadap Financial Distress Studi pada Perusahaan Manufaktur Sektor Industri Dasar dan Kimia yang Terdaftar di Bursa Efek Indonesia tahun 2012-2015). Jurnal Administrasi Bisnis S1 Universitas Brawijaya, 43(1), 138-147.

Brealey, R. A., Myers, S. C., \& Marcus, A. J. (2008). Dasar-Dasar Manajemen Keuangan Perusahaan. Erlangga.

Brigham, E. F., \& Houston, J. F. (2010). Dasar-Dasar Manajemen Keuangan (11th ed.). Salemba Empat. 
Ainnun Masita \& Purwohandoko. Analisis Pengaruh Rasio Keuangan, Kepemilikan Manajerial, dan Kepemilikan Institusional terhadap Financial Distress pada Perusahaan Sektor Perdagangan, Jasa, dan Investasi yang Terdaftar di BEI Tahun 2015-2018

Carolina, V., Marpaung, E. I., \& Pratama, D. (2017). Analisis Rasio Keuangan untuk Memprediksi Kondisi Financial Distress (Studi Empiris pada Perusahaan Manufaktur yang Terdaftar di Bursa Efek Indonesia Periode 2014-2015). Jurnal Akuntansi Maranatha, 9(2), 137-145. https://doi.org/10.28932/jam.v9i2.481

Cinantya, I., \& Merkusiwati, N. (2015). Pengaruh Corporate Governance, Financial Indicators, Dan Ukuran Perusahaan dan Financial Distress. E-Jurnal Akuntansi, 10(3), 897-915.

Curry, K., \& Banjarnahor, E. (2018). Financial Distress pada Perusahaan Sektor Properti Go Public di Indonesia. 207-221.

Damayanti, L. D., Yuniarta, G. A., \& Sinarwati, N. K. (2017). Analisis Pengaruh Kinerja Keuangan, Ukuran Komite Audit dan Kepemilikan Manajerial Terhadap Prediksi Financial Distress (Studi pada Perusahaan Manufaktur yang Terdaftar di Bursa Efek Indonesia Periode 2011-2015). EJournal S1 Ak Universitas Pendidikan Ganesha, 7(1), 1-12.

Ekawati, S. (2016). Analisis Pengaruh Likuiditas, Leverage, Ukuran Perusahaan, dan Sales Growth Terhadap Financial Distress Pada Perusahaan Manufaktur Yang Terdaftar di BEI Tahun 20132015. Jurnal Ilmu Manajemen (JIM).

Fathonah, A. N. (2017). Pengaruh Penerapan Good Corporate Governance Terhadap Financial Distress. Jurnal Ilmiah Akuntansi, 1(2), 133-150. https://doi.org/10.23887/jia.v1i2.9989

Hafizah, N. (2015). Determinants Of Financial Distress Among Manufacturing Companies In Malaysia. University Utara Malaysia.

Hanafi, M. M., \& Halim, A. (2016). Analisis Laporan Keuangan (5th ed.). UPP STIM YKPN.

Hastuti, I., \& Purwanto, E. (2015). Analisis Rasio Keuangan sebagai Alat Prediksi Financial Distress bagi Perusahaan Manufaktur di Bursa Efek Indonesia Tahun 2009-2012. FORUM AKADEMIKA, $18(1)$.

Hidayat, M. A., \& Meiranto, W. (2014). Prediksi Financial Distress Perusahaan Manufaktur di Indonesia. Journal of Accounting, 3(3), 1-11.

John, A. T., \& Ogechukwu, O. L. (2018). Corporate Governance and Financial Distress in the Banking Industry: Nigerian Experience. Journal of Economics and Behavioral Studies, 10(1), 182-193. https://doi.org/10.22610/jebs.v10i1.2101

Kasmir. (2010). Pengantar Manajemen Keuangan. Kencana Prenada Media Group.

Kasmir. (2016). Analisis Laporan Keuangan. Raja Grafindo.

Khairuddin, F., Mashuni, A. W., \& Afifudin. (2019). Pengaruh Good Corporate Governance dan Rasio Likuiditas Terhadap Financial Distress di Perusahaan Manukatur yang Terdaftar di BEI 20152018. E-Jra, 08(01).

Kurniasanti, A., \& Musdholifah. (2018). Pengaruh Corporate Governance, Rasio Keuangan, Ukuran Perusahaan dan Makroekonomi terhadap Financial Distress. Jurnal Ilmu Manajemen, 6(3), 197212.

Loman, R. K., \& Malelak, M. I. (2015). Determinan Terhadap Prediksi Financial Distress pada Perusahaan Manufaktur di Bursa Efek Indonesia. Journal of Research in Economics and Management, 15(2), 371-381. 
Marota, R., Alipudin, A., \& Maiyarash, A. (2018). Pengaruh Debt To Assets Ratio (Dar), Current Ratio (Cr) dan Corporate Governance dalam Memprediksi Financial Distress pada Perusahaan Bumn Sektor Non Keuangan yang Terdaftar di Bursa Efek Indonesia. JIAFE, 4(2), 249-266.

Nora, A. R. (2016). Pengaruh Financial Indicators, Ukuran Perusahaan dan Kepemilikan Institusional Terhadap Financial Distress (Studi Empiris pada Perusahaan Property dan Real Estate yang Terdaftar Di BEI).

Noviandri, T. I. O. (2014). Peranan Analisis Rasio Keuangan dalam Memprediksi Kondisi Financial Distress Perusahaan Sektor Perdagangan. Jurnal IImu Manajemen, 2(4).

Priyatnasari, S., \& Hartono, U. (2019). Rasio Keuangan, Makroekonomi dan Financial Distress : Studi pada Perusahaan Perdagangan, Jasa dan Investasi di Indonesia. Jurnal Ilmu Manajemen, 7, 10051016.

Pulungan, K. P. A., Lie, D., Jubi, \& Astuti. (2017). Pengaruh Likuiditas dan Leverage Terhadap Financial Distress pada Perusahaan Sub Sektor Keramik, Porselen dan Kaca yang Terdaftar di Bursa Efek Indonesia. Jurnal Financial, 3(2).

Sadida, B. D. (2018). Risk Profile , Good Corporate Governance, Earnings , and Capital ( RGEC ) Sebagai Prediktor Terhadap Kondisi Financial Distress Pada Perusahaan Perbankan. Jurnal Manajemen Dan Bisnis Indonesia, 7(4), 347-357.

Santoso, G. A. P., Yulianeu, \& Fathoni, A. (2018). Analysis of Effect of Good Corporate Governance, Financial Performance and Firm Size on Financial Distress in Property and Real Estate Company Listed Bei 2012-2016. Journal of Management.

Sari, P. A. I. (2015). Analisis Pengaruh Rasio Keuangan Terhadap Financial Distress pada Perusahaan Property dan Real Estate Yang Terdaftar di Bursa Efek Indonesia Tahun 2011. Jurnal Manajerial, l(1). https://doi.org/10.30587/manajerial.v1i1.427

Sartono, A. (2001). Manajemen Keuangan Teori dan Aplikasi. BPEF-YOGYAKARTA.

Sean, S., \& Viriany. (2016). Pengaruh Rasio Keuangan Terhadap Financial Distress pada Perusahaan Manufaktur yang Terdaftar di Bursa Efek Indonesia Periode 2009-2013. XXI(01), 43-60.

Setiawan, D., Oemar, A., \& Pranaditya, A. (2017). Pengaruh Laba, Arus Kas, Likuiditas Perusahaan, Ukuran Perusahaan, Leverage, Kepemilikan Instutisional dan Kepemilikan Manajerial untuk Memprediksi Kondisi Financial Distress. Jurnal Ilmiah Mahasiswa Akuntansi Universitas Pandanaran.

Setiawan, H., \& Amboningtyas, D. (2018). Financial Ratio Analysis for Predicting Financial Distress Conditions (Study on Telecommunication Companies Listed In Indonesia Stock Exchange Period 2010-2016). Journal of Management, 4(4).

Setiyawan, E., \& Musdholifah. (2020). Pengaruh Struktur Kepemilikan, Profitabilitas, Likuiditas, Leverage dan Nilai Tukar Terhadap Financial Distress pada Perusahaan yang Terdaftar di IDX Tahun 2016-2017. Jurnal Ilmu Manajemen (JIM), 8(1), 51-66. https://jurnalmahasiswa.unesa.ac.id/index.php/jim/article/view/30110

Setkab.go.id. (2019). Tertinggi Sejak 2014, BPS: Ekonomi Indonesia 2018 Tumbuh 5,17 Persen. https://setkab.go.id/tertinggi-sejak-2014-bps-ekonomi-indonesia-2018-tumbuh-517-persen/

Simanjuntak, C., Titik, F., \& Aminah, W. (2017). Pengaruh Rasio Keuangan Terhadap Financial 
Ainnun Masita \& Purwohandoko. Analisis Pengaruh Rasio Keuangan, Kepemilikan Manajerial, dan Kepemilikan Institusional terhadap Financial Distress pada Perusahaan Sektor Perdagangan, Jasa, dan Investasi yang Terdaftar di BEI Tahun 2015-2018

Distress (Studi Pada Perusahaan Transportasi Yang Terdaftar Di Bursa Efek Indonesia Periode 2011- 2015). E-Proceeding of Management, 4(2), 1580-1587. https://doi.org/2355-9357

Vinh, V. X. (2015). Using Accounting Ratios in Predicting Financial Distress: An Empirical Investigation in the Vietnam Stock Market. Journal of Economics and Development, 17(1), 4149.

Widhiari, N., \& Merkusiwati, N. (2015). Pengaruh Rasio Likuiditas, Leverage, Operating Capacity, dan Sales Growth Terhadap Financial Distress. E-Jurnal Akuntansi, 11(2), 456-469.

Yustika, Y. (2015). Pengaruh Likuiditas, Leverage, Profitabilitas, Operating Capacity dan Biaya Agensi Manajerial terhadap Financial Distress (Studi Empiris pada Perusahaan Manufaktur yang Terdaftar di Bursa Efek Indonesia Tahun 2011-2013. Jurnal Online Mahasiswa (JOM Fakultas Ekonomi (FE) Universitas Riau, 2(2). 